Through a left rectus incision under chloroform, the abdom. inal cavity was found full of blood with a slight odlor. The iipere portion of the rectum and all of a very redundant sigmois were split along the free margin of the intestine. Ahove the simmoid and in the lower portion of the deseencling colon two transverse tears arossed the bowel. The eflects of the air-blast, by the stretching and checking of the peritoneum as well as by the congestion of the blood-vessels, could be seen as far as the ceeum. The small intestines were collapsed and were not congested. The tear in the intentine was not completely through it. The serous and museular coats were torn through, but the mucous coat was stretehed to the thinness of tissue-paper and filled a 10-inch gap.

The mucosa was folded in by interrupted stitehes of seaisland cotton placed in the museular and serous hyers of the bowel. A donble row of stitehes was used throughout. The intestine was opened well above the traumatic area of the bowel in the descending colon. A No. 24 French eatheter was pussed out of the rectum and fastened in the bowel by one stitch of chromic catgut. The bowel was closed by interrupted stitches of sea-islund cotton and a drain was placed in the pelvis. The patient made an uneventful recovery.

In the postoperative treatment the hend of the bed was slightly elevated and gas was expelled through the tube in thirty-six hours, when water by the mouth was begun and retained withont distention. The pelvie drain was removed in one week and the rectal tube was expelled at the same time. The patient was nourished on liquids for fourteen days and at the end of that time the bowel movements became normal with the aid of an ounce of glycerin injected high up in the sigmoid throngh a small catheter. No medicine, opiates or purgatives were used by mouth or by hypodermic injection. By palpation the condition of the sigmoid could be judged at all times, and the tube in the intestine drained of the gas and some fecal matter contimously. I made no attempt to rush fecal matter over a very much sewn intestine; consequently, the stretehed mucosa of the sigmoid did not slough.

\section{A CASE OF AMEBIC DYSENTIERY TREATED WITH} EMWTIN HYIDOCHLORII

\section{R. E. Cloud; M.D., Enstidey, Ala.}

History,-S. J. G., aged 34, white, male, wus born in Kentucky and moved at the age of 17 to Decatur, Ala., where he lived about ten years. From Decatur he came to J3irmingham (Ensley), which has been his residenee continuously for the past seven years. Jight years ago he spent a month in Houston, Tex., which single trip constitutes tlle extent of his travels.

The present trouble began thiee and a half or four years ago with frequent movements of lowels (fifteen or twenty stools in twenty-four hours), struining, puin in hypogastrium and over sacrum and tenderness in epignstrium. Movements consisted mostly of blood and mucus. Attucks of this kind, more or less severe, recurred three or four times a year, usually lasting a month or more. Stools would number two or three a day during intervals between severe attacks, never being entircly free from mueus and blood and practically all accompanied by tenesmus.

At the time that the patient consulted me, September 15, he was suffering with a moderntely severe attack which had developed four or five days previous and just reached the point where he had to discontinue work.

Physical Hoamination.-Heiglit 5 feet $81 / 2$ inches, weight 140 pounds (formerly his weight averaged about 160). No evidence found of pathologic condition in thorax. Tenderness in epignstrium and lyypogastrium. Stool (passed in a vessel in my oflice), macroscopically, seemed to consist of only blood and muens; microscopically, motile amebas were found in the first ficld.

I'seatment and Results.-September 15 the putient had six or eight movements from early morning to noon. Milk diet was prescribed and $1 / 2$ grain emetin hydrochlorid given hypodermatically.
September 16. lour stools since the dily before; a little blood in the first two, mucus in all. ITmetin 1 grain.

september 17. Thres stools in last twenty four hours but no red blood in any. General appenranee yellow with some mueus. Emetin 1 grin.

September 18. Two well-formed yellow movements, a littlo mucus, no blood. No emetin given; supply exhausted.

September 19. One stool about 11 a. ni., yellow and perfectly normal in appearance. Patient suys that this is the first morning that he has not been forced to go to the toilet immediately on rising in probubly a year. No phin or strain. ing and only slight tenderness in epigastrium. A fimal dose of $1 \frac{1}{2}$ grains emetin was given, although the case, clinically, soemed cured.

September 24. Returned to work on Monday, September $2 \cdot 2$; all symptoms alsent since the 18 th nni only one movement per day since thut date. Feels "remurkably" well. Stool porfectly normal in apperanance, well formed, no sugrestion of blood or mueus.

All troatments wore given in my oflice. There was not the Jeast nausen or, in fact, any noticenble constitutional effert following injections althongh patient hat to go home on the car (about a mile) after each dose.

After the second day soft diet was allowed and on the fifth patient was told to eat whatever he desired.

$1903 \frac{1}{2}$ Avenue $\mathrm{lis}$.

\section{A SIMPTE AND PRACTICAL MIETHOD FOR TIIE PREPARATION OF PURE JUTTERMILK}

Sverme Ortenat, M.D., Crimax, Mine.

The role of luttermilk, particularly in the artificial feeding of infants and in the treatment of gistro-intestinal disorders of the first two years of life, has made its use $n$ mutter of necessity among rich and poor alike. A practicul method for its preparation secms, therefore, to be a matter of considerable importunce.

This iden was suggested throwgh a study of the recent work of Clock and others along the lines of the lnetic neid bacillus principle of trentment, and its use is largely lased on the administration of the culture of the Bacillus lactis bulgaricus, Type A (Grigoroff), although its preparation is not neossarily dependent on this form of lactic acid bacillus culture preparation.

There are two methods for the preparation of buttermilk according to this principle, the choice of which would depend on whether the physician or trained nurse is nble to carry out the work in person, or must leave it to the mother or some one alse in charge whe has no knowledge of bacteriologic or dietetic principles:

1. In carrying out this method I have olstuined the kind ussistunce and cooperation of the buttermaker in charge of a loenl crenmery. It is a well-known fact that the buttermaker uses a pure culture of lactic acid bacillus in the process of "ripening" the crenm. This culture is kept fresh by frequent renewal or "propagation." The mother or nurse is instrueted to obtain a small amount of this culture in a bottle or hermetically sealed jar, which has previously been placed in boiling water for a few ninutes and then corked or sealed. This must, of course, be kept in a cool place at the home. A pint of whole or skimmed milk, as the case sany indicate, is placed in a boiler, preferably a double boiler, brought to a boiling point over a slow fire and then cooled down to room tempera. ture without the lid of the boiler being removed. A teaspoonful of the culture (the spoon which is used having been held in boiling water for a minute or two) is then put into the milk and the whole allowed to stand at room temperature for eight hours, after which it is cooled down and kept ready for use. This method may be enrried out in any householl which has access to a creamery. It has been my experience that the buttermaker is very willing to cooperate with the physician in the work, and some remuneration may easily be arranged for. 
2. This method requires a little more scientific detail, and is best carried out by the plysician or truined nurse in person. Whole milk is cooled down to about $50 \mathrm{~F}$. immediately after milking by the vessel being immersed in ice-water. It is then pasteurized at $180 \mathrm{~F}$. for thirty minutes. After cooling down to $80 \mathrm{~F}$. implantation is carried out by the use of the tablets of B. lactis bulyaricus, Type A (Grigoroff), in the proportion of six tablets to a half pint of milk. It is kept at this temperature for eight hours, or until the milk is coagulated. If used before coagulation has taken place it will have a bitter, disagreeable taste. After coagulation, however, it assumes a very agreeable odor and taste. The culture, after being thus prepared, may be further propagated, according to the first method, by simple transplantation every twenty-four hours, and an indefinite amount of buttermilk be thus prepared. A culture may be safely carried along for two weeks, when a fresh culture should be prepared.

\section{New and Nonofficial Remedies}

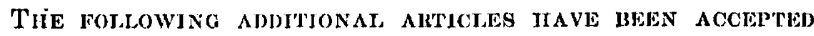

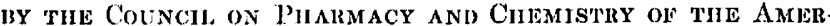
ican Menical association. Their acceptance ilas been BASED LAR(ILLY ON EVIDENCE SUPPLIED BY THE MANUFACTURRR OR HIS AUEN'T AND IN PART ON INVESTIOATIION MADE BY OR

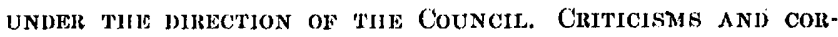
RECTIONS AIE ASKED FOR TO AIJ IN TIIE REVISION OF 'THE MA'TTER

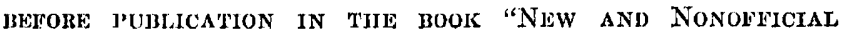
Remenies."

The Council deshes pilysicians to understand tirat the ACCEP'TANCE OF AN AR'TICLE DOES NO'T NECESSARILY MEAN A RECOMMENDATION, BUT THAT, SO FAR AS KNOWN, I'P COMPLIES WITH THE RULES ADOPTED BY THE COUNCIL.

\section{W. A. Puckner, Secreirary.}

ACNE VACCINE.-(Sce N. N. R., 1913, p. 221.)

The Ablott Laboratories (The Abbott Alkalojdal Co.), Chicago.

Acne-Bacterin Polyzalcnt.--Marketed in four syringes containing respectively 25 milliton, 50 million, 100 million and 200 million killed Bacllus Acne.

BACILLUS COLI VACCINE.-(See N. N. R., 1913, p. 221.) The Ablott Jaloratories ('The Abbott Alkaloidal Co.), Chicago.

Coll-Bactcrin Polyulent.--Marketed in four syringes contalning respectively so million, 100 million, 200 million and 400 million killed Baclllus Coll Communis.

FRIEDLAENDER VACCINE--(See N. N. R., 1913, p. 222.) The Abbott Jaboratories (The Abbott Alkaloidal Co.), Chicago.

friedlander Bacterin polyvalent.-Marketed in four syringes contuinfne lesperetlvely 50 milllon, 100 million, 200 million and 400 million killed Fildedlander bicilli.

GONOCOCCUS VACCINE.-(See N. N. R., 1913, p. 223.)

The Abbott Laboratories (The Abbott Alkaloidal Co.), Chicago.

Gonococens-Bacterin polynalent.-Marketed in four syringes containing respectively 50 million, 100 million, 200 million and 400 million killed Gonococet.

PNEUMOCOCCUS VACCINE.-(See N. N. R., 1913, p. 224.) The Abbott Laboratories (The Abbott Alkuloidal Co.), Clicago.

pneumo-Jacterin polyzatent.-Markoted in four syringes containing respectively 50 million, 100 million, 200 million and 400 million killed I'neumococel.

MIXED VACCINES.-(See N. N. R., 1913, p. 224.)

'The Abbott Laboratories (The Abbott Alkaloidal Co.), Chicago.

Staphylo-Acne.Bacterin Polyvalent.-Murketed in four syringes. Syringe 1 contulns 250 million mixed Staphylococel and 25 million Acne bacllit. 'Total 275 million killed bacteria. Syringe 2 contalns

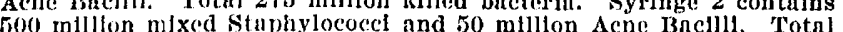
550 million lifled bacterin. Syringe 3 contains 1,000 million mlxed
Straplyylococed, and 100 millinn Acne Rnellli, Total 1,100 million killad bacterta. Syringe 4 contnins 2,000 millton mixed Stnpliylococel and 200 million $A$ cne Baclili. Totas 200 million killed bacterla.

STAPHYLOCOCCUS VACCINES.-(See N. N. R., 1913, p. 225.)

The Abbott Laboratories (The Abbott Alkaloidal Co.), Chicago.

Staphylo-A7jus-Bsacterin Polpvalent. - Marketed in four syringes, contuining respectlvely 200 million, 400 million, 800 million and 1,000 million killed staphylococcus albus.

staphylo-A urens-Bacterin polpvalent.-Marketed in four syringes contalning respectively 200 million, 400 million, 800 million ind 1,000 million killed Stinplylococeus Aureus.

Staphylo-Bacterins (Humalu) Albus-Anreus-Citreus.-Marketed in four syringes containing respectively 200 million, 400 million, 800 million and 1,000 millfon killed bucteria.

STREPTOCOCCUS VACCINE.-(See N. N. R., 1913, p. 226.) The Abbott Laboratories (The Abbott Alkaloidal Co.), Chicago.

Strepto-Bacterin (Scarlatina Bacterin) Polyvalent.-Marketed in four syringes contuining respoctively 50 million, 100 million, 200 million and 400 million killed streptococei from senrlet fever cases.

Antistreptococcic Vaceine (Scarlatina Prophylactic).-Marketed in packages of throe syringes contufning respectively 250 million, 500 million and 1,000 million killed streptococel from scurlet fever cases.

Strepto-Bactern (Human) Pollyvalent.-Marketed in four sylinges containlng respectively 50 million, 100 mlllion, 200 million and 400 million kflled streptococet.

TYPHOID VACCINE.-(Sce N. N. R., 1913, p. 227.)

The Abbott Laboratories (The Ablott Alkuloidal Co.), Chicago.

Typho-Bactein Polyvalent.-Marketed in four syringes contnining respectlyely $100 \mathrm{~m}$ lllion, $200 \mathrm{mllli}$ oll, 400 million and 800 million killed Typhold bactlli.

Typhoid Prophylactie.-Marketed in packuges containing three syringes, contuining respectlvely 500 million, 1,000 million and 1,000 million killed bacteria.

ARHEOL.-Arheol is santalol, $\mathrm{C}_{15} \mathrm{H}_{20} \mathrm{OH}$, a sesquiterpenic alcohol, the ehief constituent of sandulwood.

Actions and Uses: The action of arlicol is the same as that of sundalwood oil. It is claimed that because of its purity it does not occusion disturbance of the stomach or the kidney. It is asserted to be useful in urethritis, cystitis and vesical catarrh, especially from gonorrhea.

Dosage: 0.40 to $0.60 \mathrm{gm}$. ( 6 to 9 grains). Arheol is marketed only in cupsules containing 0.20 Gm. (3 grains) of which 9 to 12 capsules are to be taken daily.

Munufactured by Alexander Astler, Parts, France. No U. S. patent. U. S. trudemurk No. 72,5̃13.

Arhcol Capsules.- Euch capsule contuins Artheol $0.2 \mathrm{Gm}$. (3 grains).

Arheol is a colorless, ofly liquld; speetfe glavity, 0.979 at $15 \mathrm{C}$. It is insoluble in witer but soluble in alcohol. It bolls under 11 mm. pressure at 160 degrees, and under ordinary pressure at about $500 \mathrm{C}$

\section{Therapeutics}

\section{PUERPERAL JNIEECTION}

This discussion does not aim to be dogmatic, but suggestive. Though septic infection after parturition occurs much less often than even a few ycar's ago, it is still sufficiently frequent to necessitate resort to every possible method of prevention and to the thorough consideration of effective but non-meddlesome treatment.

This infection occur's most frequently in one of two general forms. One is a typical blood-poisoning or sapremia, which is caused by the absorption of toxins or decomposition products of substances that are undergoing putrefactive or other chemical changes in the genital tract. Of course the most frequent substances causing such poisoning are retained fragments of the placenta or membranes, or, if there is any obstruction to the exit of the normal lochia, there may be absorption from this. 